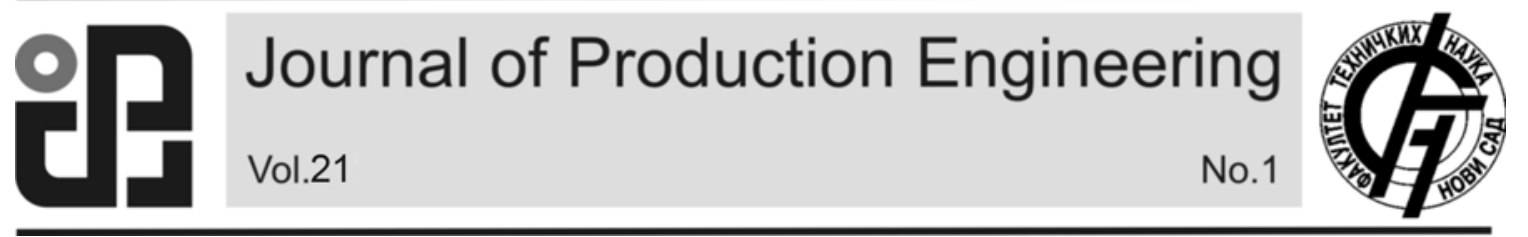

Skrijelj, H., Jović, S.

\title{
CHIP FORM PREDICITON BY COMPUTATIONAL INTELLIGENCE TECHNIQUES
}

\author{
Received: 27 April 2018 / Accepted: 30 May 2018
}

\begin{abstract}
The main aim of the investigation was to predict chip form based on machining parameters and surface roughness. Straight turning of mild steel and AISI 304 stainless steel were performed. Spindle speed, feed rate, depth of cut and surface roughness of the material were used as inputs. Computational intelligence techniques could be used for the prediction process. In this article support vector regression (SVR) was applied for the chip form prediction. The SVR model was compared with other computational intelligence models like artificial neural network (ANN) and genetic programing (GP) techniques as benchmark models. The crucial aim of the study was to predict favorable and unfavorable chip form according to the machining parameters. By the way one should make optimal machining conditions in order to avoid unfavorable chip form. Based on the results, SVR ( $\left.R^{2}: 0.9682\right)$ model outperformed $A N N\left(R^{2}: 0.8367\right)$ and $G P\left(R^{2}: 0.7753\right)$ model for the chip form prediction..
\end{abstract}

Key words: chip form; prediction; machining parameters; surface roughness

Predikcija oblika strugotine primenom metoda veštačke inteligencije. Glavni cilj ovog istraživanja je određivanje prediktivnog modela za oblike strugotine na osnovu različitih parametara rezanja $i$ hrapavosti obrađene površine. Obrada skidanjem strugotine je izvršena na mekom čeliku AISI 304. Brzina, pomak i dubina rezanja kao i hrapavost obrađene površine su parametri koji su korišćeni kao ulazni parametri. Pošto je proces formiranja strugotine veoma kompleksan u ovom radu je korišćena metoda veštačke inteligencije za kreiranje predktivnog modela. Korišćena je vektorska metoda regresije (SVR). SVR rezultati su upoređeni sa rezultatima dobijenim primenom veštačke neuronske mreže (ANN) i genetskog programiranja (GP). Glavni cilj ovog rada je predvideti poželjne $i$ nepoželjne oblike strugotine na bazi ulaznih parametra. Time bi u startu procesa bile eliminisane mogućnosti pojave nepoželjnih oblika strugotine jer ti oblici sturgotine mogu negativno da utiču na komoletan proces obrade materijala. Na osnovu rezultata, SVR $\left(R^{2}: 0.9682\right)$ model ima veću tačnost od $A N N\left(R^{2}\right.$ : 0.8367) i GP ( $R^{2}$ : 0.7753) modela za predikciju oblika strugotine.

Ključne reči: oblik strugotine, predikcija, obrada struganjem, hrapavost površine

\section{INTRODUCTION}

Chip form is crucial factor during mechanic process since it has high influence on the stability of the machining process [1]. For example long chips can have harmful impacts on the process of the material removing and on the product quality as well and small chips can be handled and transferred in storage easily [2].

Different parameters of the machining process are influential on the alternations of the chip form. To prevent the formation of the unfordable chip form one needs to analyze which machining parameters have the highest influence on the chip form. [3] To perform good chip control one needs to understand the chip form creation. Results of study [4] were gave clear ideas to the tool designer, technologist, or even to the foreman, as to what kind of chip-breaking should be used for a given set of machining conditions. In article [5] was developed a basic 3-D analysis of the geometry of chip forms with a view to determining the relationship between the geometry of steady-state 3-D helical chips and the 2-D concepts of pure up-curl and pure side-curl. In paper [6] was presented results of an experimental study on finish turning of steels with cermet chip forming tool inserts and based on this analysis, the paper was proposed the need for establishing a "total machinability" assessment criterion for optimum machining performance of a "cutting toolwork material-machine tool" system. Chips produced during lathe turning should be broken so as to prevent snarling and to enhance heat removal from the tool [7]. Paper [8] concluded that there is the consistency between theoretical and experimental results in terms of chip geometries and volumes under different cutting speeds and feed rates. In paper [9] was attempted to develop a computer-aided process planning system incorporating a predictive capability for chip breakability in turning operations. The issue of chip control has plagued continuous operations the most. An automatic system for chip breaking detection in turning was developed in article [10].

Although the modelling of the chip form has been proposed in several investigations [11, 12], the main goal in this study was to avoid high nonlinearity of the mathematical approaches by using computational intelligence methodology $[13,14]$. In this investigation support vector regression (SVR) [15, 16, 17, 18, 19, 20] was used to predict the chip form based on different machining parameters and surface roughness as well. SVR was compared with artificial neural network (ANN) and genetic programming (GP) models as benchmark methods. 


\section{METHODOLOGY}

\subsection{Experimental measurement}

Experimental tests of turning tests was made on mild steel and AISI 304 stainless steel on the machine
Model CM6241X1000. According to the ISO standard [21] eight chip form types were generated (Table 1) for different machining parameters and different surface roughness of material as it shown in Table 2.

\begin{tabular}{|l|l|l|}
\hline 1 Ribbon Chips & Chip form classification \\
\hline 2 Tabular Chips & & \\
\hline 3 Spiral Chips & & \\
\hline 7 Elemental Chips & & \\
\hline
\end{tabular}

Table 1. Chip form types [21] for this study

\begin{tabular}{cll}
\hline Inputs & $\begin{array}{l}\text { Parameters } \\
\text { description }\end{array}$ & $\begin{array}{l}\text { Process } \\
\text { parameters } \\
\text { values }\end{array}$ \\
\hline input 1 & $\begin{array}{l}\text { Spindle speed } \\
\text { [rpm] }\end{array}$ & $108-900 \mathrm{rpm}$ \\
\hline input 2 & $\begin{array}{l}\text { Feed rate } \\
{[\mathrm{mm} / \mathrm{rev}]}\end{array}$ & $\begin{array}{l}0.05-0.13 \\
\mathrm{~mm} / \mathrm{rev}\end{array}$ \\
\hline input 3 & $\begin{array}{l}\text { Depth of cut } \\
{[\mathrm{mm}]}\end{array}$ & $0.2-1.5 \mathrm{~mm}$ \\
& $\begin{array}{l}\text { Surface } \\
\text { roughness } \\
{[\mu \mathrm{m}]}\end{array}$ & $\begin{array}{l}0.694-6.973 \\
\mu \mathrm{m}\end{array}$ \\
\hline input 4 & \\
\hline
\end{tabular}

Chip forms are categorized as favorable and unfavorable according to the ISO 3685:1993 standard [21]. In this study eight chip forms were used and these forms are categorized as follow:

- $\quad$ 1.1 Long - Unfavorable: 0

- $\quad 2.3$ Snarled - Unfavorable: 0

- 3.1 Flat - Unfavorable: 0

- 4.1 Long - Unfavorable: 0

- 4.2 Short-Favorable: 1

- 4.3 Snarled - Unfavorable: 0

- 6.2 Loose - Favorable: 1

- 7 Elemental Chips - Favorable: 1

Table 2. Input parameters 


\subsection{SVR methodology}

SVR (support vector regression) working standard depends on the information mapping in characterized spaces by nonlinear mapping. A straight calculation performs in the component space. In the event that the inward item in the element space is accessible as a capacity specifically in light of the first info focuses, it is conceivable to influence nonlinear figuring out how to machine which is known as piece work, $\mathrm{K}$. The portion capacity could certainly diagram the information to the higher dimensional element space. Straight arrangement in the higher dimensional element space is associated with nonlinear arrangement in the first, bring down dimensional information space. There are distinctive portion work. In this investigation we utilized outspread premise work as bit work since it is the most widely recognized portion work. The principle advantage of the spiral premise work is computationally effectiveness. The non-straight spiral premise piece work is defined as:

$$
K\left(x, x_{i}\right)=\exp \left(-\frac{1}{\sigma^{2}}\left\|x-x_{i}\right\|^{2}\right)
$$

where $x$ and $x_{i}$ are vectors in the input space.

Since SVR is data driven model, adequate consideration of the factors controlling the SVR is crucial to developing a reliable SVR model.

To assess the SVR success and other soft computing techniques, two statistical indicators were used as follows:

1) Root-mean-square error (RMSE)

$$
R M S E=\sqrt{\frac{\sum_{i=1}^{n}\left(P_{i}-O_{i}\right)^{2}}{n}}
$$

2) Coefficient of determination $\left(R^{2}\right)$

$$
\mathrm{R}^{2}=\frac{\left[\sum_{\mathrm{i}=1}^{\mathrm{n}}\left(\mathrm{O}_{\mathrm{i}}-\overline{\mathrm{O}_{\mathrm{i}}}\right) \cdot\left(\mathrm{P}_{\mathrm{i}}-\overline{\mathrm{P}_{\mathrm{i}}}\right)\right]^{2}}{\sum_{\mathrm{i}=1}^{\mathrm{n}}\left(\mathrm{O}_{\mathrm{i}}-\overline{\mathrm{O}_{\mathrm{i}}}\right) \cdot \sum_{\mathrm{i}=1}^{\mathrm{n}}\left(\mathrm{P}_{\mathrm{i}}-\overline{\mathrm{P}_{\mathrm{i}}}\right)}
$$

where $P_{i}$ and $O_{i}$ are known as the experimental and forecast values, respectively, and $n$ is the total number of test data.

\section{RESULTS}

Figure 1 shows prediction results of the chip form by the computational intelligence techniques. The chip form was based on ISO 3685:1993 standard [21]. Eight classes of the chip form were used in this study. Based on the observation of the results in Figure 1 one can conclude that SVR model outperformed ANN and GP models. Also the number of underestimated chip form values are limited for the SVR model.

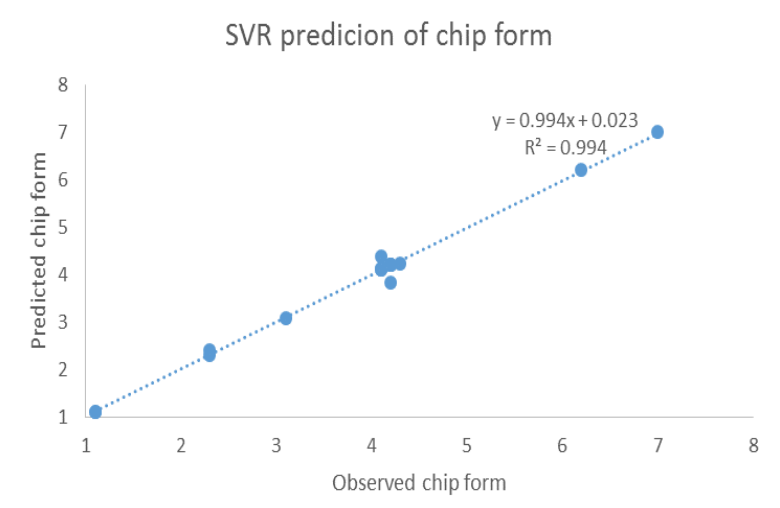

(a)

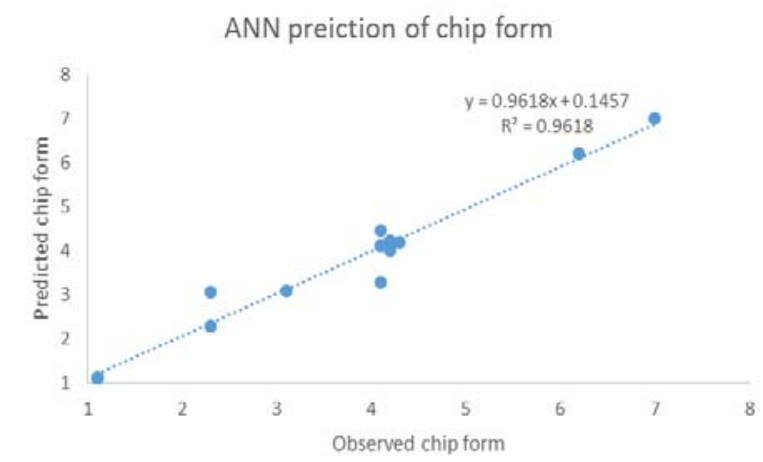

(b)

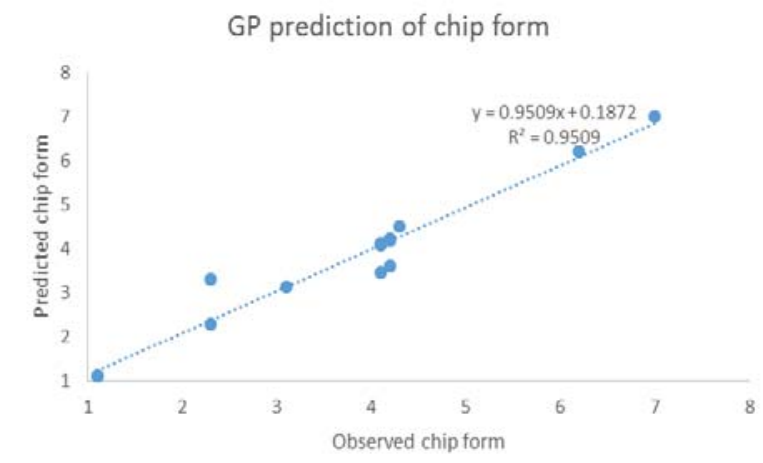

(c)

Fig. 1. Forecasting of chip form with: (a) SVR, (b) ANN and (c) GP model

Furthermore Figure 2 shows prediction results of the chip status form by the same computational intelligence techniques. There are two status of the chip status: favorable and unfavorable. The main goal was to minimize the unfavorable chip status form.

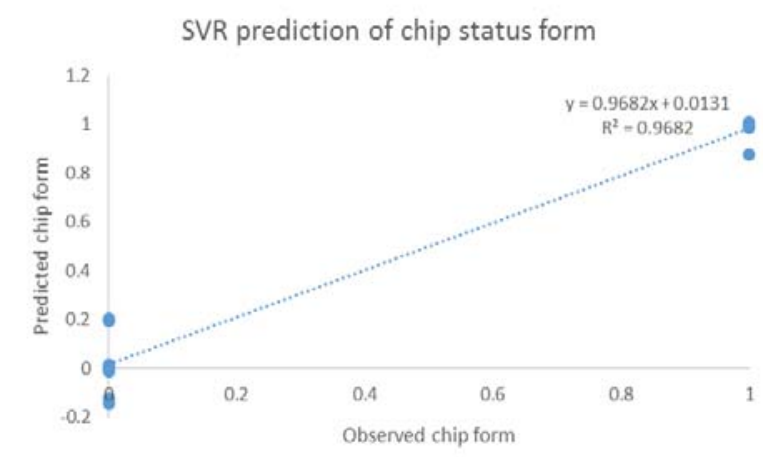

(a) 
ANN prediction of chip status form

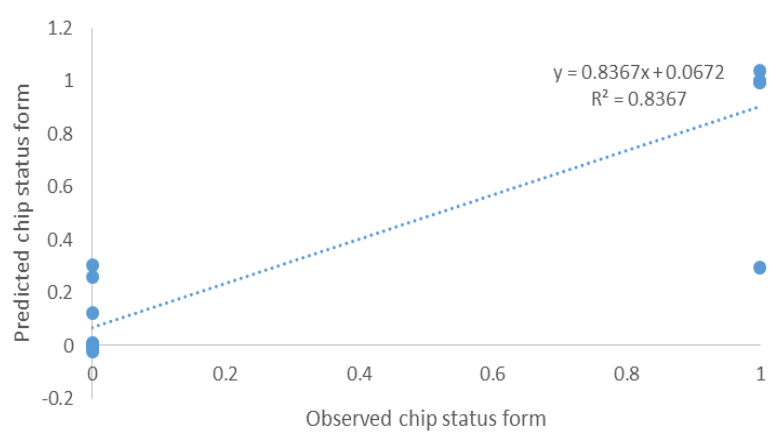

(b)

GP prediction of chip status form

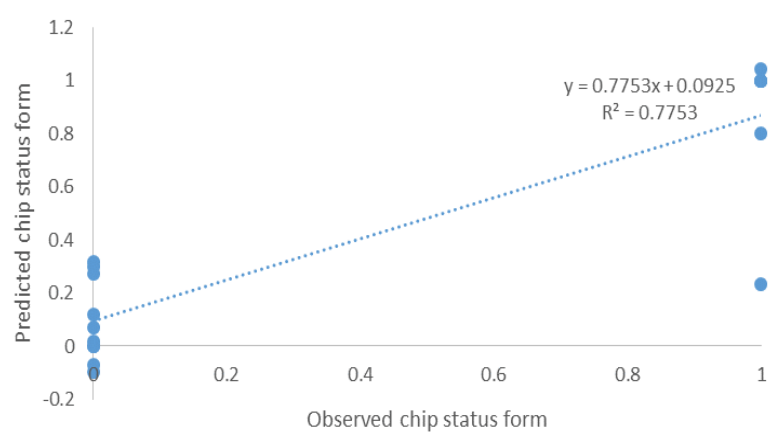

(c)

Fig. 2. Forecasting of chip status form with: (a) SVR, (b) ANN and (c) GP model

Table 3 compares the SVR models with the ANN and GP models based on RMSE and $\mathrm{R}^{2}$ indices for the chip form prediction and chip status prediction as well. One can note drastic differences between SVR, ANN and GP results for chip status prediction.

\begin{tabular}{l|l|l|l|l}
\hline & & SVR & ANN & GP \\
\hline $\begin{array}{l}\text { Chip } \\
\text { form } \\
\text { prediction }\end{array}$ & $\mathrm{R}^{2}$ & 0.994 & 0.9618 & 0.9509 \\
\cline { 2 - 5 } & RMSE & 0.1144 & 0.2884 & 0.3269 \\
\hline $\begin{array}{l}\text { Chip } \\
\text { status } \\
\text { form } \\
\text { prediction }\end{array}$ & $\mathrm{R}^{2}$ & 0.9682 & 0.8367 & 0.7753 \\
\cline { 2 - 5 } & RMSE & 0.0878 & 0.1989 & 0.2333
\end{tabular}

Table 3. Performance of the computational intelligence techniques

\section{CONCLUSION}

The main aim of the article was to establish an algorithm for chip form prediction based on different machining parameters and surface roughness as well. Chip form was analyzed according to ISO 3685:1993 standard. The chip form prediction was complex due to the many factors. Therefore in this study was applied a computational intelligence methodology to overcome the prediction difficulties of the chip form. Based on the results, SVR $\left(\mathrm{R}^{2}:\right.$ 0.9682) model outperformed ANN $\left(R^{2}: 0.8367\right)$ and GP $\left(R^{2}: 0.7753\right)$ model for the chip form prediction.

\section{REFERENCES}

[1] Dimla, D. E., Application of perceptron neural networks to tool-state classification in a metalturning operation. Engineering Applications of Artificial Intelligence 12(4) (1999) 471-477.

[2] Sánchez, E. R. A. C. J., \& Marcos, S. M., Chip arrangement in the dry cutting of aluminium alloys, Journal of Achievements in Materials and Manufacturing Engineering 16 (2006) 1-2.

[3] Gziut, O., Kuczmaszewski, J., \& Zagórski, I., Impact of depth of cut on chip formation in az91hp magnesium alloy milling with tools of varying cutting edge geometry, Advances in Science and Technology Research Journal 9(26) (2015) 49-56.

[4] Astakhov, V. P., Shvets, S. V., \& Osman, M. O. M., Chip structure classification based on mechanics of its formation, Journal of Materials Processing Technology 71(2) (1997) 247-257.

[5] Kharkevich, A., \& Venuvinod, P. K., Basic geometric analysis of 3-D chip forms in metal cutting.: Part 1: determining up-curl and side-curl radii, International Journal of Machine Tools and Manufacture 39(5) (1999) 751-769.

[6] Jawahir, I. S., Qureshi, N., \& Arsecularatne, J. A., On the interrelationships of some machinability parameters in finish turning with cermet chip forming tool inserts, International Journal of Machine Tools and Manufacture 32(5) 709-723.

[7] Ralston, P. A. S., Stoll, K. E., \& Ward, T. L., Fuzzy logic control of chip form during turning, Computers \& industrial engineering 22(3) (1992) 223-230.

[8] Ralston, P. A. S., Stoll, K. E., \& Ward, T. L., Fuzzy logic control of chip form during turning, Computers \& industrial engineering 22(3) (1992) 223-230.

[9] Balaji, A. K., Ghosh, R., Fang, X. D., Stevenson, R., \& Jawahir, I. S., Performance-based predictive models and optimization methods for turning operations and applications: part 2assessment of chip forms/chip breakability, Journal of manufacturing Processes 8(2) (2006) 144-158.

[10] Andreasen, J. L., \& De Chiffre, L., Automatic chip-breaking detection in turning by frequency analysis of cutting force, CIRP AnnalsManufacturing Technology 42(1) (1993) 45-48.

[11] Teti, R., Jawahir, I. S., Jemielniak, K., Segreto, T., Chen, S., \& Kossakowska, J., Chip form monitoring through advanced processing of cutting force sensor signals, CIRP AnnalsManufacturing Technology 55(1) (2006) 75-80.

[12] Tangjitsitcharoen, S., \& Moriwaki, T., Intelligent monitoring and identification of cutting states of chips and chatter on $\mathrm{CNC}$ turning machine, Journal of Manufacturing Processes 10(1) (2008) 40-46.

[13] Chungchoo, C., \& Saini, D., On-line tool wear estimation in CNC turning operations using fuzzy neural network model, International Journal of 
Machine Tools and Manufacture 42(1) (2002) 2940.

[14] Abdullah, K. U. R. T., \& SEKER, U., Investigation of the effects of different chip breaker forms on the cutting forces using artificial neural networks, Gazi University Journal of Science 25(3) (2012) 803-814.

[15] Ananthakrishnan, S., Prasad, R., Stallard, D., \& Natarajan, P., Batch-mode semi-supervised active learning for statistical machine translation, Computer Speech \& Language 27(2) (2013) 397-406.

[16] Ye, Q., Zhang, Z., \& Law, R., Sentiment classification of online reviews to travel destinations by supervised machine learning approaches, Expert systems with applications 36(3) (2009) 6527-6535.

[17] Rajasekaran, S., Gayathri, S., \& Lee, T. L., Support vector regression methodology for storm surge predictions, Ocean Engineering 35(16) (2008) 1578-1587.
[18] Yang, H., Huang, K., King, I., \& Lyu, M. R., Localized support vector regression for time series prediction, Neurocomputing 72(10-12) (2009) 2659-2669.

[19] Wei, Z., Tao, T., ZhuoShu, D., \& Zio, E., A dynamic particle filter-support vector regression method for reliability prediction, Reliability Engineering \& System Safety 119 (2013) 109116.

[20] Zhang, L., Zhou, W. D., Chang, P. C., Yang, J. W., \& Li, F. Z., Iterated time series prediction with multiple support vector regression models, Neurocomputing, 99 (2013) 411-422.

[21] Standard, I. S. O., Tool Life Testing with SinglePoint Turning Tools. ISO/DIS, 8688. (1986).

Authors: Professor Srđaj Jović PhD, Assoc. Professor Hivzo Skrijelj PhD, University of Priština, Faculty of Technical Sciences in Kosovska Mitrovica, Kneza Milosa 7, 38220 Kosovska Mitrovica, Serbia.

E-mail: hivzos@yahoo.com srdjanjovic2016@hotmail.com 